\title{
Independent Financial Adviser (IFA)-based brand equity pyramid
}

\begin{abstract}
This paper aims to evaluate the applicability of the existing brand equity pyramid models in the context of independent financial advisers (IFAs) in the UK financial services sector. Nine in-depth interviews with IFAs and nine in-depth corroboration interviews with senior marketing managers and employees in one of the UK's largest financial services providers were undertaken for the purpose of the study. The findings indicate that when applied in the context of IFAs, the existing brand equity pyramid models require modification. These findings lead to the development of an IFA-based brand equity pyramid. The new model can provide insight for financial services marketing academics and practitioners on how IFAs perceive and evaluate financial services brands to be recommended to their customers. Our findings will help financial services providers to develop strong brands in the mind of IFAs.
\end{abstract}

Keywords: brand equity, brand equity pyramid, brand resonance, intermediaries, independent financial advisers 


\section{Independent Financial Adviser (IFA)-based brand equity pyramid}

\section{Introduction}

This paper aims to address a gap in the brand equity literature by exploring whether the brand equity model, originally developed for B2C markets (Keller, 2001; Keller and Swaminathan, 2020) and modified for B2B markets (Kuhn, Alpert and Pope, 2008; Ćorić and Jelić, 2015), is applicable in the UK’s independent financial advice sector. Even though the existing marketing literature recognises that intermediaries, such as independent financial advisers (IFAs), are a key marketing asset that enables providers to reach out to and serve endcustomers, to date there has been little brand equity research undertaken in the context of IFAs. What studies there are have suggested that brand equity can be extended to other constituencies such as suppliers, partners, distributors, employees or other stakeholders who are involved within the brand network (e.g. Raggio and Leone, 2007; Stockman et al., 2020; Theurer et al., 2018).

IFAs are recognised as the strongest distribution channel of long-term savings, pensions, annuities and protection products in the UK (Gough, 2005; Financial Conduct Authority [FCA], 2019). They are viewed as the agent of customers and as having a duty of care to provide the best possible outcome for their client's financial needs across the full spectrum of financial services product providers in the marketplace (Ennew, Waite and Waite, 2018) . Despite their significant role, only limited number of business and marketing studies were conducted in the context of IFAs (Gough, 2005; Gough and Nurullah, 2009; Grierson and Brennan, 2017). Most financial services branding studies to date have been in the context of banking in the end customers market (de Chernatony and Cottam, 2006; Dawes, 2014; Rambocas, Kirpalani and Simms, 2014; Moin, Devlin and McKechnie, 2016; Du Preez, 
2017). Therefore, conducting a branding study in the context of the IFAs will be a valuable contribution to both financial services marketing academics and practitioners.

The UK’s Financial Services Authority (FSA) launched the Retail Distribution Review (RDR) in 2013 and and Financial Advice Market Review (FAMR) in 2015. The purpose of the RDR is to reconsider how investments are distributed to retail consumers in the UK. The FAMR aims to develop a market which delivers affordable and accessible financial advice and guidance to everyone in a post-RDR environment (FCA, 2016a). The RDR was developed to increase consumer confidence in financial advice by removing the potential for commission bias and increasing the professionalism of financial advisers. It requires financial advisers to adhere to the minimum level of qualifications, improve the transparency of charges and services and remove commission payments to advisers and platforms from product providers. Due to these changes, advisory and product provider firms have been evaluating their business models and making the necessary changes to meet these requirements. The RDR is likely to influence the dynamics of the relationship between the providers, IFAs, and customers. Furthermore, because the RDR does not allow the IFAs to receive commission from providers anymore, they may use different criteria for selecting brands to recommend to their clients.

Utilising a qualitative research method in form of interviews with IFAs as well as corroboration interviews with senior marketing managers and employees of one of the largest financial services providers in the UK, this article aims to contribute to the brand equity, channel relationship and financial services marketing literature. The contribution of this studies is twofold. Firstly, the present study is one of the first studies since the RDR that investigates the criteria used by IFAs to evaluate the added value offered by financial services 
brands. Secondly, the present study offers a modification of brand equity pyramid in the context of IFAs. The sub-dimensions in the IFA-based brand equity pyramid can be used by both academics and practitioners to develop a brand equity measurement for measuring the strength of financial services brands in the mind of IFAs.

\section{Literature review}

\subsection{Brand equity in business markets}

The concept of brand equity was originally introduced in the end customer market (Zhang et al., 2016). Brand equity describes the customers’ perceptions towards a brand which in turn leads to the generation of value of the brand (de Chernatony et al., 2011). Therefore, strong brand equity is required to build a strong brand (Aaker, 1991; Keller, 2001). The extensive brand equity literature to date has recognised various sources of brand equity (e.g. Aaker, 1991; Ćorić and Jelić, 2015; Kuhn et al., 2008), which emphasises that the sources of brand equity differ from context to context.

As IFAs operate as businesses they are considered as business customers. It is recognised that brand equity in business markets can equally result in positive outcomes as in end customer markets (Biedenbach, 2012; Kumar, Cohen and Rajan, 2015). Studies on branding in business markets indicates that brand is a critical consideration in the decision making process (Bendixen, Bukasa and Abratt, 2004; Kalafatis et al., 2012). However, end customerbased brand equity cannot easily be applicable in the business market (Kuhn, Alpert and Pope, 2008; Keränen, Piirainen and Salminen, 2012; Zhang et al., 2016). This is due to the different characteristics between end and business customers. For instance, business customers are considered to be more rational in their decision making so that the emotional values that are often emphasised in $\mathrm{B} 2 \mathrm{C}$ branding are deemed inappropriate in the context of B2B (Leek and Christodoulides, 2012; Mogaji, Czarnecka and Danbury, 2017). Functional 
values such as quality, price and delivery are important factors that will influence the decision making of B2B customers (Bogomolova and Romaniuk, 2010; Mogaji, Czarnecka and Danbury, 2017). Furthermore, a relationship-based approach is considered more appropriate in this business environment because of high degree of interaction, exchange of information, investments in stock, and resultant high costs to the buyer in switching suppliers (Donaldson and O’Toole, 2007). Nevertheless, the existing studies often imply that B2B branding concepts are generally applicable in any industries, regardless of the industry characteristics and circumstances (Ćorić and Jelić, 2015). Therefore, it is the intention of this article to fill in the gap in the literature by examining the applicability of one of the most cited brand equity models in the literature, Keller’s (2001) customer-based brand equity pyramid, in the context of the UK IFA sector.

\subsection{Brand equity pyramid models}

According to Keller (2001), a strong brand is created by fulfilling each of the steps contained in the brand equity pyramid model, which consist of brand identity, brand meaning, brand responses and brand resonance. When the model is applied in two different B2B contexts, waste management for Australian city councils (Kuhn, Alpert and Pope, 2008) and chemical products in Southern and Eastern Europe (Ćorić and Jelić, 2015), modification is needed to suit the characteristics and nature of each industry. Whilst the steps of the existing brand equity pyramids remain the same, there are variable differences in their proposed dimensions and sub-dimensions.

The first step of building a strong brand is to develop a strong brand identity by developing strong brand salience (Keller, 2001). Studies on B2B brand equity models (Ćorić and Jelić, 
2015; Kuhn et al., 2008) confirm that brand salience is relevant in the context of a B2B market, but B2B buyers appear to focus on corporate, rather than product, brand salience. The second step is developing brand meaning by cultivating brand image which characterises the brand and how it should stand in customers’ minds. Brand meaning consists of brand performance (functional needs) and imagery (psychological and social needs) (Keller, 2001). The elements of brand performance and imagery are applicable in the context of B2B buyers, but they also look for some indicators of longevity and proof that the supplier will be able to assist them in the future (Ćorić and Jelić, 2015; Kuhn et al., 2008). Therefore, in the B2B brand equity pyramids, company reputation is more relevant and significant than brand imagery.

The third step is developing favourable brand responses which consists of brand judgement and brand feelings (Keller, 2001). Brand judgement involves how customers put together different performance and imagery associations for the brand to form different kinds of opinions. Brand feelings are customers' emotional responses and reactions with respect to the brand and relate to the social currency evoked by the brand. Whilst the elements of brand judgement are found to be applicable in the B2B market, brand feelings are found to be irrelevant, indicating that the purchase process is more rational than emotive (Ćorić and Jelić, 2015; Kuhn et al., 2008). Instead, they find that relationships with company representatives are more applicable in the B2B market.

The last step, brand relationship (Ćorić and Jelić, 2015; Keller, 2001; Kuhn et al., 2008), is about developing brand resonance. When a brand achieves resonance, consumers have a deep psychological bond with it and consumers' activities will be inspired by their loyalty towards the brand. In the B2B brand equity pyramid (Kuhn et al., 2008), brand resonance is replaced 
by partnership solutions. Kuhn et al. (2008) do not find the evidence of behavioural loyalty, feelings of affiliation, or kinship with other users and the willingness of the B2B customers to get to know the brand better. On the other hand, Ćorić and Jelić (2015) identifies that both resonance (Keller, 2001) and partnership solutions (Kuhn et al., 2008) are relevant in the B2B chemical sector.

The above comparison identifies that whilst the steps of building brand equity remain the same, there are some differences between the B2C and B2B brand equity pyramids which can be the result of the differences in industry characteristics and context of where the studies had taken place. Therefore, this study aims to contribute to the brand equity literature by evaluating the applicability of the existing brand equity pyramid models in the context of IFAs in the UK's financial services sector.

\subsection{The role and characteristics of IFAs}

This study aims to investigate the applicability of the brand equity pyramid in the context of IFAs. IFAs provide unbiased and unrestricted financial advice which meet a customer's needs and objectives by considering and recommending all types of retail investment products from all firms across the market (Financial Conduct Authority [FCA], 2016b). The main services offered by IFAs are financial advice on more complex financial services such as retirement planning, taxation and investments (Grierson and Brennan, 2017). IFAs are different from restricted advisers, who only recommend certain products and/or providers (Financial Conduct Authority [FCA], 2016b).

Developing a strong brand is deemed to be particularly important in the professional services (Kim and Hyun, 2011) and financial services (Devlin and Azhar, 2004; de Chernatony and Cottam, 2006) sectors, as a result of the intangibility and high perceived risk of the offerings 
(Biedenbach and Marell, 2010). Furthermore, financial advice is high in credence qualities (Paswan et al., 2004). Customers who received advice from a financial adviser can only evaluate that advice when it was experienced (Ennew, Waite and Waite, 2018). Only the most fanatical investment enthusiasts will be able to determine whether the financial advisers have made the best investment decision in particular markets (Harrison, 2000). In addition, the offerings in the financial services sector are relatively homogenous (Howcroft and Durkin, 2003) and providers tend to be viewed as relatively undifferentiated (Paswan et al., 2004). As the marketing of financial services is heavily regulated, conventional marketing practices are often not permitted in this sector (Grierson and Brennan, 2017). When initial expectations of financial services are vague, customers may devote greater effort and time to pre-purchase activities and rely on other informative cues or credible sources (Tam, 2006), such as IFAs, whose expertise and skills are the key elements of the service provided.

IFAs can be seen as intermediaries who connect providers with end customers and provide a range of services (Jensen, 2010). Their in-depth market knowledge and role as a channel intermediary resemble the characteristics of B2B buyers. They interact closely with service providers and on a very frequent basis (Hausman, 2003) and the success of their relationship is based on a regular constructive and innovative interaction (Kong and Mayo, 1993). They have a fundamental role in the channel relationship because they hold access to the customers; add value to the supplier's products; help to create new values with customers; and reduce the supplier's costs of maintaining customers (Gordon, 1998). They are increasingly involved in the way that products and services are designed, assembled, promoted and delivered (Duncan and Moriarty, 1997). Furthermore, they apply their personal and professional values to judge the performance of a firm and they are likely to use this judgment to form opinions and attitudes towards brands (Foley and Kendrick, 2006; 
Anisimova and Mavondo, 2014). Thus, building relationships with intermediaries, such as IFAs, and understanding their expectation can reinforce provider's brand values (Martin and Hetrick, 2006).

\section{Research methods}

The benefit of using qualitative research to determine causal relationships is that the researcher will not only understand that a particular thing happens, but how and why it happens (Miles, Huberman and Saldana, 2014). By adopting a qualitative method, this study will not only attempt to identify what added value is considered important by IFAs when evaluating long-term saving and investment brands but also provide an explanation of why these added value elements are considered important and therefore, inform the process of how the brands can develop strong brand equity. In-depth interviews were the most appropriate method adopted for the purpose of this study. The aim of an in-depth interview is to explore the respondents' perspective and to capture in their own words, their thoughts, perceptions, feelings, and experiences (Brinkmann, Kvale and Flick, 2018).

Thirty potential Scotland-based IFAs were identified through Unbiased.com and invited to participate in the study. Nine IFAs from nine different companies agreed to participate in the study. Interviews were conducted with the IFAs to evaluate their views on branding, and the criteria and the process they employed in selecting financial services brands. All IFAs are customer-facing and have managerial responsibilities in their company. Their experience as a financial adviser range from 10 and to over 30 years. Each interview was between 60 and 120 minutes. Theoretical saturation was achieved after the fifth interview as no new themes and categories emerged from the data (Payne, 2016). However, in order to ensure that all 
categories and variations in the data were identified and represented (Hawker and Kerr, 2016), we conducted further four interviews.

Face-to-face interviews were also conducted with nine senior managers and employees of one of the largest financial services providers in the UK to corroborate the findings of the study. The provider was keen to participate in the study because more than three quarters of their sales were generated through IFAs. The authors were also given an opportunity to access the provider's internal market research reports and documents about the IFA market. The senior managers and employees who participated in the study have various functional marketing roles which include branding, marketing, market research, relationship management and distribution. The interviews lasted between one to two hours.

The interviews were audio-recorded, transcribed and analysed by using Nvivo. The study adopted axial coding, which allocated codes from the conceptual frameworks to chunks of text (Sobh and Perry, 2006) and enabled the process of looking for relationships between the categories of data (Saunders et al., 2009). Prior to the data collection, a list of codes which contains the steps (brand identity, meaning, responses and relationship) and dimensions (awareness, performance, imagery, reputation, judgments, feelings, buyer-seller relationship and brand resonance) of the brand equity pyramid models was generated. The interview data was assigned to these codes and new codes were added when the data revealed relevant information, such as sub-dimensions, which were not mentioned in the existing models. After this process was completed, the codes were organised and compared with the existing brand equity pyramid models (Ćorić and Jelić, 2015; Keller, 2001; Kuhn et al., 2008). 


\section{Findings and analysis}

The findings of this study will be reported using the four steps outlined in the existing brand equity pyramid models starting with brand identity.

\subsection{Brand identity}

The findings indicated that all interviewed IFAs had preferred brands. In order to recommend certain brands to their clients, first the IFAs must recognise or be aware of the brand, If you have a direct identical thing scenario, you would choose the one that you are more comfortable with. There is a natural degree of comfort if you deal with something that you know. It's a customer's nature that you want to be associated with the company that's doing well (IFA 6).

As the industry experts, the IFAs are more likely to have an extensive knowledge about available brands in the market and which product categories are offered by these brands. In addition to this knowledge, the IFAs were also able to recall which brand was considered as the "expert" in each product category. Therefore, it will be more difficult for providers who do not have deep and broad brand awareness or are not associated with certain expertise to compete with those who have.

The interviews with the IFAs also revealed that if they were not aware about a brand but they offer competitive offerings, they would evaluate the brand and the company thoroughly before placing any business with them. The majority of the IFAs emphasised how big and famous brands, which were well-recognised by the general public and could be considered as successful, did not necessarily become the best providers, 
Provider $\mathrm{C}$ is the biggest brand in the UK, but we don't use them for other reasons. Provider F is a very small brand, when they came to speak to us, we have different concerns like we wanted to know how financially robust is this, what the people are like, we went to [a city], we had them in here, we met the senior managers in here, we organised it for two years before we chose the wrap, but the brand, they would fail on that. So, I don't think it's as important as the insurance companies, the big insurance companies have strong brands, they think it's really important, I don’t agree (IFA 3).

All interviewed senior managers and employees added that most long-term saving and investment brands "have very low spontaneous awareness and very high prompted awareness” (Marketing Director) amongst end customers. Furthermore, because long-term saving and investment offerings were advised products, providers relied on IFAs’ recommendations to their clients. Therefore, as the IFAs are influential opinion makers in this industry, it is very fundamental for financial services providers to establish a deep and broad brand awareness amongst the IFAs.

\subsection{Brand meaning}

This study has identified several factors that are considered important by IFAs in evaluating the functional values of the brand or brand performance. These were range of products; product performance; product features; price (charges); technological and training supports; service; and information accuracy. Although functional differentiations were desired, all IFAs and company representatives recognised that little differences could be found in the range of products, product performance and product features offered by different brands. When little difference existed, the IFAs added that they often evaluated price offered by providers to find the best offer. Nevertheless, whilst price was an important factor in the 
IFAs’ decision making process, it was not the ultimate factor. Instead, they highlighted the importance of service, information accuracy, and technological and training support in selecting providers and they emphasised how these often became their main consideration when choosing providers, especially in light of the changes in the regulatory environment,

I think with RDR, it's important that we all work together and there is transparency when we talk about fees and commissions. The clients can understand [them] and the service aspect is done together and respectably for the benefits of the clients. Because it's not going be easy, it's going to be different, but I think it's a good thing. With the RDR, IFAs will become more professional and more qualified and service to clients is better. I am up for that, and now the provider has to play on that [too]. There is quite a lot of information coming out from the company in regard to RDR, so you are really kept up to speed with it (IFA 9)

In addition to evaluating the functional values of financial services brands, in making their decision, the IFAs also evaluated how a brand could fulfil their psychological and social (emotional) needs. However, instead of focusing on the external properties of the product and services or the imagery of the brand, the findings illustrated that the IFAs paid more attention to the company's profile and track record. This study identified that the size and type of organisation; personality traits and values; commitment; longevity and experience were the sub-dimensions used by the IFAs in evaluating the provider's reputation.

All IFAs mentioned that they had a relationship with various types and sizes of financial organisations such as banks, insurance providers, pension providers and boutique investments houses. They indicated that the size of the organisation did not matter as long as they had 
good knowledge about the organisation, but they would not be comfortable in dealing with providers that were considered too small.

During the interviews all IFAs often made a comparison between a provider who was easy to deal with or down-to-earth and a provider who was bureaucratic. An IFA summarised that the approach taken by a down-to-earth provider was "If there is a problem, there must be some kind of solution, let's find it first” (IFA 3). The approach taken by a bureaucratic company was "This is the way that it has been done so this is the way that things have to be done" (IFA 3). He suggested that these characteristics came across in the way that the company conducted its business and dealt with its employees and IFAs. Other traits and values mentioned by the IFAs in describing the providers were reliable, sincere, competent, ethical, innovative and successful.

Commitment and longevity were considered fundamental characteristics that IFAs sought in providers. Knowing the providers' level of commitment to the market was important, "Because all the time somebody comes into a particular market and then leaves it” (IFA 8). All IFAs highlighted that a provider's longevity was also a sign of the provider's security and stability. Supporting this argument, one of the senior managers added,

I think it's also about, people or consumers have a confidence in who they are placing their business with, that they can trust us. They know that we are going to be around for a long time. Because there is a longevity of the products that they are buying, that company has that longevity (Market Research Manager)

Past experiences with the brand were also considered to be fundamental for the IFAs when choosing providers. All IFAs pointed out that they would hesitate to choose providers who have mishandled their business in the past. 


\subsection{Brand responses}

All IFAs suggested that although they had access to all providers in the marketplace, they use a product panel in evaluating the quality of products proposed by the providers.

So, there is kind of a rigid panel at the provider level and for the investment choice and the funds we had about 60 funds that we limit our recommendation to and the work that we do there is relentless really and according to our regular meetings with fund managers and things like that (IFA 3).

The IFAs' usage of a product panel illustrates how the IFAs evaluate the functional values offered by the providers.

Furthermore, as their brand choice could reflect their credibility as an IFA, they were more likely to consider a brand which they trusted. All senior managers and employees also added the importance of understanding the IFAs' business models and developing trust, especially because of the regulatory changes.

Post RDR they are looking for a brand that can help them to grow their business.

Because the whole business model is changing and they want a brand that understands a different business model that can help them and support them as they manage and grow their business and be that trusted partner that their clients ultimately want as well (Brand Manager).

The IFAs also revealed that there were always providers who were considered superior to others in terms of their products, services and managing relationships, but no provider was 
good at everything. When considering relevant products and services, all IFAs frequently mentioned how their choice must cater for their clients’ needs and preferences, for instance,

A product from company like Provider K, if it's a predicted product but may be much more expensive but they offer their clients a peace of mind about security, some clients are willing to pay for that peace of mind (IFA 9).

Because of the complexity and the long-term nature of the products, all interviewed IFAs mentioned that they would choose providers who provided safety, stability and assurance in the delivery of their offerings and avoid those who did not.

All interviewees highlighted the importance of the relationship between providers’ representatives and IFAs. This relationship often became a key factor that determined the IFAs’ brand choice. All IFAs highlighted that having a face-to-face relationship with the provider's account managers was preferable to having a telephone-based relationship. They believed that because the account managers had access to various departments within the company, they could solve problems more effectively and efficiently.

The senior managers and employees also confirmed that the importance of managing relationship with IFAs at the front line as well as the senior management levels. Nevertheless, due to costs, only IFAs who were profitable and valuable to the providers are allocated faceto-face account managers, as suggested by one of the senior managers, "Like any business $80 \%$ of our business comes from $20 \%$ of the market. There are businesses who give us very little and they tend to be picked up by the telephone account management team” (IFA 
Distribution Manager). Thus, a face-to-face relationship between the IFAs and the account managers can be an indication of a strong relationship between the providers and the IFAs.

\subsection{Brand relationship}

In addition to the fulfilment of the functional and emotional values, the evidence indicated that the IFAs in the study showed behavioural loyalty. They would not hesitate to recommend the same brands repeatedly when they had a satisfying experience in the past. All IFAs also mentioned that although they have access to the whole market, they had several brands that were considered as their main providers. These providers often managed a large amount of their business. Nevertheless, they also highlighted that despite their preferred list, they would monitor their performance very closely.

The findings also indicated that the IFAs were keen to get involved in a brand community and maintained active engagement with providers if they have a strong relationship with the brand and the brand community was aimed at improving the provider's service. The IFAs stated that even though they received many invitations from various providers to get involved in their engagement activities, they were only willing to spend their time, effort and energy in the activities if they had a strong relationship with the providers. Furthermore, when the IFAs had a good relationship with the brands, they also wanted to help the brands to develop solutions or new propositions. They believed that only by getting involved in active engagements with the brands, they could influence the brands' direction and create brands that would suit their and their clients’ needs,

Ultimately it is for our clients. Just if you'd like to see something happening for your clients, and there is a gap. You know like, we really like this product, but you don't 
do this thing. If you can add that up, that will be brilliant so then we can talk to our clients, look this product is really good for you because it does all of those things that we want it to do. Provider G is quite open in that respect. We are making a suggestion and we have the head of the marketing in here two or three times. I don't know how many companies do that, but I think we are on their list. We are on their top account. So, we are the one that they want to come to and speak to us (IFA 7).

Table 1 provides further examples of participant responses in relation to the brand equity dimensions. 
Table 1 Examples of participant responses in relation to the brand equity dimensions

\begin{tabular}{|c|c|c|}
\hline \multirow[b]{2}{*}{ Identity } & \multirow[b]{2}{*}{ Salience } & $\begin{array}{l}\text { I've got an email yesterday. The reason that I remembered it because Inever heard of them. So, I } \\
\text { pressed delete (IFA 7). }\end{array}$ \\
\hline & & $\begin{array}{l}\text { I don't think that clients are so concern about the brand of providers because they just want to make } \\
\text { sure that their money are safe. But they're really looking towards the relationship that they have with } \\
\text { us to recommend a provider. To make sure that it meets with their objectives (IFA 5). }\end{array}$ \\
\hline & \multirow{2}{*}{$\begin{array}{l}\text { Performance } \\
\text { - } \text { Range of products } \\
\text { - } \text { Product performance } \\
\text { - } \text { Prices (charges) } \\
\text { - Financial strength } \\
\text { Technological \& } \\
\text { training support }\end{array}$} & $\begin{array}{l}\text { I look at what funds that the providers' platform gives me access to, what are the } \\
\text { charges for the wrap, what are the annual management charges, what I can put into } \\
\text { their portfolio. Charges are paramount. And obviously, what analytical tools that } \\
\text { they've got. The fancy the back-office stuffs that I can show my clients (IFA 4). }\end{array}$ \\
\hline & & $\begin{array}{l}\text { One of the key things that we look at for clients, when we were recommending an } \\
\text { investment for clients, is what the service is like, what's our experience like with the } \\
\text { company's service like because we are only choosing financial services companies } \\
\text { that deliver us good service (IFA 3). }\end{array}$ \\
\hline
\end{tabular}




\begin{tabular}{|c|c|c|}
\hline \multirow{3}{*}{ Meaning } & $\begin{array}{l}\text { - } \text { Service } \\
\text { - Information accuracy }\end{array}$ & $\begin{array}{l}\text { There are a lot of providers out there that we don't have particularly good relationship } \\
\text { and that could be because their product mix doesn't match what our client is looking } \\
\text { for. It could be their service level could be terrible (IFA 5). }\end{array}$ \\
\hline & $\begin{array}{l}\text { Reputation } \\
\text { - } \quad \text { Size \& type of } \\
\text { organisation } \\
\text { - Personality \& values } \\
\text { - Commitment }\end{array}$ & $\begin{array}{l}\text { It comes back to the continuity of things really. The other one thing is their } \\
\text { willingness to commit to a market, into a particular market. Because all the time there } \\
\text { is somebody comes into a particular market and then leaves it. So, you are looking for } \\
\text { somebody who really has a commitment to deal with the product and give you all of } \\
\text { the support. And generally, know what they are doing (IFA 8). }\end{array}$ \\
\hline & $\begin{array}{l}\text { - Longevity } \\
\text { - Experience }\end{array}$ & $\begin{array}{l}\text { There was an article this morning that Provider E is shutting down four of their UK } \\
\text { retail division business. If it doesn't work, then they cut it off. They have done that } \\
\text { for years. So, that's why I never really trust using them. If I put my clients on } \\
\text { something that is quite good, what happens if something is not working out for them } \\
\text { or not profitable enough for them, they have no hesitation, to just pull the thing off. } \\
\text { (IFA 7). }\end{array}$ \\
\hline
\end{tabular}




\begin{tabular}{|c|c|c|}
\hline & & $\begin{array}{l}\text { It's not the customers' experience but it’s my experience that influences. If I can't } \\
\text { trust them to send something as simple as quote that's correct, that I asked for. Then, } \\
\text { how can they look after my clients' money? (IFA 1). }\end{array}$ \\
\hline \multirow{3}{*}{ Responses } & \multirow{3}{*}{$\begin{array}{l}\text { Judgments } \\
\text { • Quality }\end{array}$} & $\begin{array}{l}\text { We have a preferred list which means that effectively we have done our due diligent } \\
\text { on a number of providers out there. We keep monitoring these providers. If one of } \\
\text { them does something hideously wrong or they fall off the planet in terms of servicing } \\
\text { and product and how they are interacting with us, they will then be replaced by } \\
\text { somebody else (IFA 5). }\end{array}$ \\
\hline & & $\begin{array}{l}\text { So, you shouldn’t have a favourite. But what you do if you have a direct identical } \\
\text { thing scenario, you would choose the one that you are more comfortable with (IFA 6). }\end{array}$ \\
\hline & & $\begin{array}{l}\text { I know providers have strong points and weak points. So, some of them will be good } \\
\text { in the ISA market and some providers will be good in the pension markets, some } \\
\text { providers will be good in the protection market. But there is not really anything that } \\
\text { set one another or good in everything (IFA 1). }\end{array}$ \\
\hline
\end{tabular}




\begin{tabular}{|c|c|c|}
\hline & - Security & $\begin{array}{l}\text { You want to have a security. You don't want to have a conversation with clients and } \\
\text { say you see that investment that I recommended to you I thought it was really good } \\
\text { but it turned out not. You don't want ever again to have that conversation (IFA 7). }\end{array}$ \\
\hline & IFA-provider relationship & $\begin{array}{l}\text { If you find a company that you are dealing with and their contract is fine. Even } \\
\text { though, the competitor's contract maybe pretty much the same, but you like dealing } \\
\text { with that company. You will deal with that company. And if you have somebody who } \\
\text { deal with you on a face-to-face basis rather than over the telephone, then obviously it } \\
\text { means that you want to develop that relationship more than dealing with somebody in } \\
\text { the other end of the country (IFA 2). }\end{array}$ \\
\hline Relationships & $\begin{array}{l}\text { Resonance } \\
\text { - Loyalty } \\
\text { - Attachment }\end{array}$ & $\begin{array}{l}\text { We don't have relationship criteria. You look at the product if it's the right thing for } \\
\text { you. If it's an investment you look at it on the panel, is it good, better, or anything } \\
\text { else. If everything is equal then, if the charges are the same. But it's very seldom the } \\
\text { case. And then you look at the company who has the longest standing relationship } \\
\text { with or you won't screw it up for the better case (IFA 6). }\end{array}$ \\
\hline
\end{tabular}




\begin{tabular}{|c|c|c|}
\hline & $\begin{array}{l}\text { - } \text { Community } \\
\text { - } \text { Engagement } \\
\text { - } \text { Partnership solutions }\end{array}$ & $\begin{array}{l}\text { I think it's important because we are the guys on the ground and we are the guys who } \\
\text { know what the customers want and what the customers are looking for. In designing } \\
\text { products, I think IFAs should be involved in that (IFA 9). }\end{array}$ \\
\hline
\end{tabular}




\section{Discussion}

This section discusses the applicability of the existing brand equity pyramid models in the context of IFAs.

\subsection{Brand identity}

The findings highlighted the importance of building brand salience amongst IFAs. As experts that can provide independent advice, IFAs are likely to shape and influence their clients' perception towards providers. Awareness and knowledge about providers are fundamental for the IFAs because they are responsible for recommending the brands to their clients and IFAs' recommendation reflects their credibility and competency. Therefore, confirming the existing brand equity models (Ćorić and Jelić, 2015; Keller, 2001; Kuhn et al., 2008), building strong brand salience through providing a deep and broad brand awareness of the organisation to IFAs is the first step of building a strong and positive brand identity.

\subsection{Brand meaning}

The next stage that must be fulfilled in building strong brand equity is about establishing brand meaning which consists of functional and emotional values. The findings of the study illustrated that the range of products, product performance, product features, price (charges), technological and training supports, service, and information accuracy were the functional values sought by IFAs when evaluating providers’ offerings. Therefore, brand performance is relevant in the context of IFAs, but its sub-dimensions need to be modified to suit the nature of the industry. The findings confirm that functional values significantly influence the decision making of B2B buyers, such as IFAs (Bogomolova and Romaniuk, 2010; Mogaji, Czarnecka and Danbury, 2017). 
Despite the emphasis on functional values, the findings confirmed that functional differentiations were difficult to be found in this industry (Howcroft and Durkin, 2003). Thus, when evaluating a brand, the IFAs also appraised how the brand could fulfil their emotional needs (Leek and Christodoulides, 2012; Mogaji, Czarnecka and Danbury, 2017). However, instead of focusing on the external properties of the product and services or the imagery of the brand, the interviewed IFAs paid more attention to the characteristics of the providers. These include the size and type of organisation, personality traits and values (down-to-earth, reliable, sincere, competent, ethical, innovative and successful), commitment, longevity and experience. Therefore, in line with the B2B brand equity models (Ćorić and Jelić, 2015; Kuhn et al., 2008), this study suggests that in the context of IFAs, reputation is more relevant than imagery. It reflects either positively or negatively on the provider's past performance and their position and standing within its current environments. However, focusing on the reputation alone can lead to unattractive product offerings (Ettenson and Knowles, 2008). Thus, providers also need to explain and emphasise the points-of-parity and point-ofdifference between themselves and other providers. In doing so, they could establish and reinforce their own brand meaning.

\subsection{Brand responses}

The next stage of the brand equity pyramid is about how customers respond to a brand, its marketing activity and other sources of information. The findings suggested that when the IFAs put together all the different associations of brand performance and company’s reputation to form opinions, they were looking for providers that can provide quality, credibility, consideration, superiority and security. 
The IFAs' usage of a product panel or best advice list illustrates how the IFAs evaluate the quality of the offerings proposed by the providers. Post-RDR the panel must also show evidence that appropriate research has been undertaken and the product selection does not compromise the IFAs’ independence (Miller, 2013). Perceived expertise and trustworthiness emerged as the factors that were used by the IFAs in evaluating brand credibility. Furthermore, when IFAs evaluated providers, they would take their clients’ needs into consideration. Therefore, they would only consider brands that were relevant and appropriate for their clients. The IFAs stipulated that providers were often known to be superior in certain areas, but not all areas. Thus, when recommending providers to their clients, IFAs would choose providers who were considered superior in fulfilling the clients’ specific needs. Because of the long-term nature and deferred benefits characteristics of the products (Ennew, Waite and Waite, 2018), security becomes an important brand evaluation within this industry. Similarly, the findings of the study confirmed that security was important to the IFAs. Their secured feeling when choosing a brand were likely to occur from their rational evaluation of the elements of brand performance as well as the elements of reputation such as commitment, longevity and experience. Therefore, whilst in Keller's (2001) model, security belongs to brand feelings, in this study, brand security is more appropriate to be classified as the subdimension of brand judgement.

A relationship between company representatives and customers is paramount in the success of B2B business relationships (Donaldson and O’Toole, 2007). The current study also confirmed the importance of the relationship between the providers' representatives and IFAs. This relationship often becomes a key factor that determines the IFAs' brand choice and indicates the strength of the relationship between the providers and the IFAs. The company's representatives' attitudes and behaviours may reflect upon the company's image 
perceived by the external stakeholders (King and Grace, 2008). Therefore, it is very important to ensure that the provider's representatives understand and are committed to the brand values that are communicated to the IFAs.

\subsection{Brand relationship}

This study identifies that all sub-dimensions of brand resonance proposed in Keller’s(2001) model are relevant in the context of IFAs. These findings are not in line with Kuhn et al.'s (2008) model which argues that resonance is irrelevant and is more in line with Ceric and Jelic’s model (2015) which emphasises both brand resonance and partnership solutions.

The findings showed that all IFAs would not hesitate to recommend the same brands repeatedly when they had a satisfying experience in the past. Despite their access to the whole market, the IFAs had several brands whom they considered as the "main providers". In the context of B2C customers, attitudinal attachment is shown in customers's strong personal attachment to the brand to the extent that the customers would say that they "love" the brand or see it as a "little pleasure" that they look forward to (Keller, 2001, p.15). Nevertheless, in the context of IFAs, attitudinal attachment occurs when the brand can fully satisfy their needs.

As the majority of the IFAs are small businesses, getting involved in a brand community in order to discuss the company's brand with their fellow IFAs is considered as a timeconsuming process. But all IFAs mentioned that they were willing to participate in a brand community if they had a strong relationship with the brand and the community was aimed at improving the provider's service. The strongest affirmation of brand loyalty is when customers are willing to invest time, energy, money, or other resources in the brand beyond 
those expended during consumption of the brand (Keller, 2001). The findings indicated that the IFAs were willing to spend their time, effort, and energy in the activities if they had a strong relationship with the providers. When the IFAs had a good relationship with the brands, they wanted to help the brands to develop solutions or new propositions. The IFAs believed that only by getting involved in active engagements with the brands, could influence the brands' direction and create brands that would suit their needs.

The discussion above results in the proposition of an IFA-based brand equity pyramid (Figure 1), which consists of four steps. First, establishing relevant brand identity by developing strong breadth and depth of brand awareness. Second, creating the appropriate brand meaning through strong, favourable, and unique brand performance and reputation. Third, eliciting positive brand responses through favourable brand judgment and establishing a strong intermediary provider relationship. Fourth, forging brand relationships by developing intense resonance and meaningful solutions. 
Figure 1 IFA-based brand equity pyramid

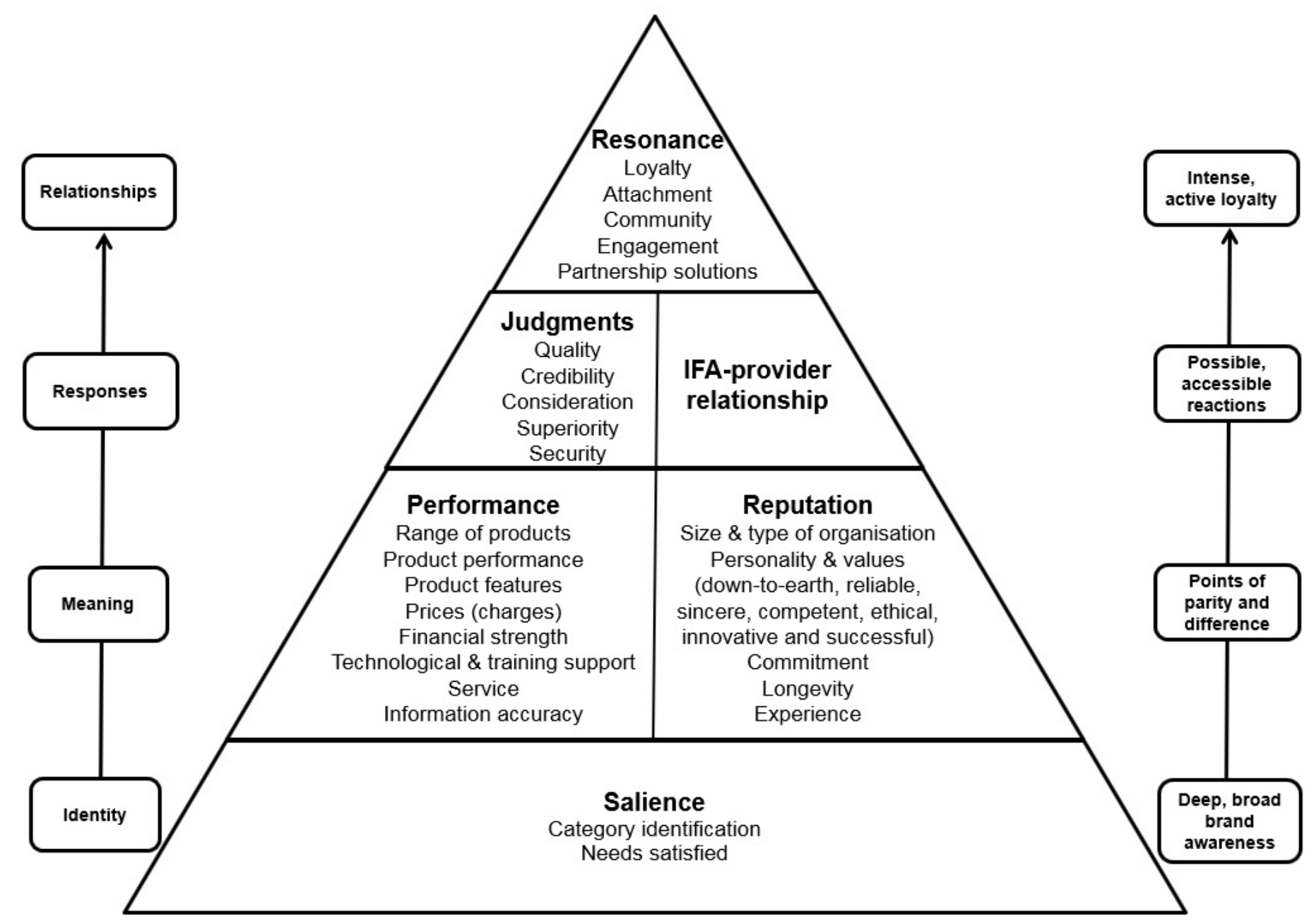




\section{Conclusions and managerial implications}

This article aims to evaluate the applicability of the existing models of brand equity pyramid (Ćorić and Jelić,2015; Keller, 2001; Kuhn et al., 2008) in the context of IFAs. The findings have shown that when the existing models are applied in the context of IFAs, their sub-dimensions need to be modified. The IFA-based brand equity pyramid illustrates the importance of creating brand awareness amongst the intermediaries (brand salience); which brands functional and emotional values are considered important (brand performance and reputation); how they evaluate these values (brand judgment and intermediary provider relationship); and how they become loyal to the brands (brand resonance). It also emphasises that a brand can only make an impact if it can offer authentic functional and emotional values and these values must also align with the IFAs' and their clients' values. Therefore, the model can guide providers in the financial services sector to propose the most appropriate brand values for IFAs and develop strong brand equity.

Because of the IFAs' significant influence on their clients' financial decision making and choice of providers, it is more beneficial for providers to create deep and broad brand awareness to the IFAs. As offerings in this industry are about financial gain and wealth management, brand functional values become dominant factors evaluated by the IFAs. To maximise their investment in the brand, providers should first gain trust from IFAs by delivering exceptional functional values and then seek to build their appreciation of certain emotional values. 
In this industry, brand emotional values are evaluated by the providers' reputation which is portrayed in their profile and the way they conduct their business. Thus, corporate branding is deemed to be more relevant for financial services providers. More importantly, the emotional values evaluation is also highly influenced by the IFAs’ relationship with the account managers who can be perceived as the living representatives of the brand. Consequently, providers should find ways to ensure that their representatives understand and are committed to the brand values that are communicated to the IFAs.

Once the brand reaches the pinnacle of the IFA-based brand equity pyramid, the IFAs are more likely to repeat purchase, get involved in engagement activities facilitated by the brands, and help the brands to find solutions or develop new brand propositions. The discussion has revealed that in order to be chosen by the IFAs, a brand should be able to continuously match its functional and emotional values with the IFAs' desired values.

As IFAs’ advice and brand recommendation reflect their credibility in the eyes of their clients, IFAs tend to choose providers whom they know well and trust. Therefore, to enhance IFAs' trust and commitment and build strong brand equity, providers must consistently deliver their brand promises to the IFAs and their clients.

\section{Limitations and future research}

The IFA based brand equity has provided a valuable insight on which brand functional and emotional values were considered important by the IFAs and how they evaluated these values. The proposed model is a starting point in developing a reliable 
IFA-based brand equity measurement or brand tracking. Nevertheless, because of the credence quality characteristics, the success of complex financial services brands (e.g. fund management, insurance, and pension) can only be truly evaluated until (often long) after consumption. The current research has found that the dimensions of B2C and B2B brand equity pyramids need to be adapted to the context of IFAs, future research could examine the applicability of these models in different industry contexts.

\section{References}

Aaker, D. A. (1991) 'Managing brand equity: Capitalizing on the value of a brand name’, California Management Review, 38(3), pp. 102-120.

Anisimova, T. and Mavondo, F. (2014) 'Aligning Company and Dealer Perspectives in Corporate Branding: Implications for Dealer Satisfaction and Commitment’, Journal of Business-to-Business Marketing. Routledge, 21(1), pp. 35-56. doi: 10.1080/1051712X.2014.857501.

Bendixen, M., Bukasa, K. and Abratt, R. (2004) 'Brand equity in the business-tobusiness market’, Industrial Marketing Management, 33(5), pp. 371-380.

Biedenbach, G. (2012) Brand building in the business-to-business context: The brand equity perspective, Faculty of Social Sciences, Umeå School of Business and Economics (USBE). Umeå University.

Biedenbach, G. and Marell, A. (2010) 'The impact of customer experience on brand equity in a business-to-business services setting', Journal of Brand Management, 17, pp. 446-458.

Bogomolova, S. and Romaniuk, J. (2010) 'Brand equity of defectors and never boughts in a business financial market', Industrial Marketing Management, 39, pp. 
$1261-1268$.

Brinkmann, S., Kvale, S. and Flick, U. (2018) Doing Interviews. 2nd edn. London: Sage Publications.

de Chernatony, L. and Cottam, S. L. (2006) 'Why are all financial services brands not great', Journal of Product and Brand Management, 15(2), pp. 88-97.

de Chernatony, L., McDonald, M. and Wallace, E. (2011) Creating powerful brands. 4th edn. Oxford: Butterworth - Heinemann.

Ćorić, D. S. and Jelić, D. (2015) ‘Applicability of Keller’s brand equity model in the B2B chemical market’, Economic Research-Ekonomska Istraživanja, 28(1), pp. 1006-1017. doi: 10.1080/1331677X.2015.1100841.

Dawes, J. G. (2014) 'Patterns in competitive structure among retail financial services brands', European Journal Marketing, 48(5/6), pp. 924-942. doi: 10.1108/EJM-022012-0085.

Devlin, J. F. and Azhar, S. (2004) “"Life would be a lot easier if we were a Kit Kat”: Practitioners' views on the challenges of branding financial services successfully', Journal of Brand Management, 12(1), pp. 12-30. Available at: http://proquest.umi.com/pqdweb?did=704176901\&Fmt=4\&VInst=PROD\&VType=P QD\&RQT $=309 \& \mathrm{VName}=\mathrm{PQD} \&$.

Donaldson, B. and O’Toole, T. (2007) Strategic market relationships: From strategy to implementation. Chichester, England: Wiley.

Duncan, T. and Moriarty, S. E. (1997) Driving brand value: Using integrated marketing to manage profitable stakeholder relationships. New York: McGraw-Hill. Ennew, C. T., Waite, N. and Waite, R. (2018) Financial Services Marketing: An International Guide to Principles and Practice. 3rd edn. London: Routledge. Ennew, C. and Waite, N. (2013) Financial services marketing: An international guide 
to principles and practice. 2nd edn. New York, NJ: Routledge.

Ettenson, R. and Knowles, J. (2008) ‘Don’t confuse reputation with brand’, MIT Sloan Management Review, 49(2), pp. 18-21.

Financial Conduct Authority [FCA] (2016a) Financial advice market review: Final report. Available at: https://www.fca.org.uk/publication/corporate/famr-finalreport.pdf (Accessed: 1 December 2017).

Financial Conduct Authority [FCA] (2016b) Types of investment adviser | FCA. Available at: https://www.fca.org.uk/consumers/types-investment-adviser(Accessed: 5 September 2018).

Financial Conduct Authority [FCA] (2019) The retail intermediary market 2018. Available at: https://www.fca.org.uk/data/retail-intermediary-market-2018 (Accessed: 1 January 2020).

Foley, J. and Kendrick, J. (2006) Balanced brand: How to balance the stakeholder forces that can make or break your business. San Francisco, CA: Jossey-Bass. Gordon, I. H. (1998) Relationship marketing. Etobicke, Canada: John Wiley \& Sons Canada.

Gough, O. (2005) 'Independent Financial Advisers - Why they remain the strongest distribution route for pensions', The Service Industries Journal, 25(5), pp. 709-720. Gough, O. and Nurullah, M. (2009) 'Undertanding what drives the purchase decision in pension and investment products', Journal of Financial Services Marketing, 14(2), pp. 152-172.

Grierson, S. and Brennan, R. (2017) 'Referrals for new client acquisition in professional services’, Qualitative Market Research: An International Journal, 20(1), pp. 28-42. doi: 10.1108/QMR-04-2016-0039.

Harrison, T. (2000) Financial services marketing. Harlow, England: Pearson 
Education Limited.

Hausman, A. (2003) 'Professional service relationships: A multi-context study of factors impacting satisfaction, re-patronisation and recommendations', Journal of Services Marketing, 17(3), pp. 226-242.

Howcroft, B. and Durkin, M. (2003) 'Editorial: Effective marketing management in financial services contexts’, Journal of Marketing Management, 19(9-10), pp. 911914.

Jensen, L.-M. (2010) 'Opportunities and constraints for intermediaries in distribution: The challange of variety', The IMP Journal, 4(3), pp. 194-219.

Kalafatis, S. P. et al. (2012) 'The differential impact of brand equity on B2B cobranding', Journal of Business \& Industrial Marketing, 27(8), pp. 623-634. doi: 10.1108/08858621211273574.

Keller, K. L. (2001) 'Building customer-based brand equity: A blueprint for creating strong brands', Journal of Marketing Communications, 15(2-3), pp. 139-155. doi: 10.1080/13527260902757530.

Keller, K. L. and Swaminathan, V. (2020) Strategic brand management: Building, measuring and managing brand equity. 5th edn. Harlow, England: Pearson Education Limited.

Keränen, J., Piirainen, K. A. and Salminen, R. T. (2012) 'Systematic review on B2B branding: research issues and avenues for future research', Journal of Product \& Brand Management, 21(6), pp. 404-417. doi: 10.1108/10610421211264892.

Kim, J.-H. and Hyun, Y. J. (2011) ‘A model to investigate the influence of marketingmix efforts and corporate image on brand equity in the IT software sector', Industrial Marketing Management. Elsevier, 40(3), pp. 424-438. doi:

10.1016/J.INDMARMAN.2010.06.024. 
King, C. and Grace, D. (2008) ‘Internal branding: Exploring the employee’s perspective’, Journal of Brand Management, 15(5), pp. 358-372.

Kong, R. and Mayo, M. C. (1993) 'Measuring service quality in the business-tobusiness context', Journal of Business \& Industrial Marketing, 8(2), pp. 5-15. Kuhn, K.-A. L., Alpert, F. and Pope, N. K. L. (2008) ‘An application of Keller’s brand equity model in a B2B context', Qualitative Market Research: An International Journal, 11(1), pp. 40-58.

Kumar, V., Cohen, G. S. and Rajan, B. (2015) ‘Industrial Marketing Management Establishing brand equity among business-to-business referral sources in the

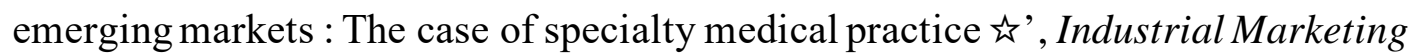
Management. Elsevier Inc., 51, pp. 26-34. doi: 10.1016/j.indmarman.2015.04.018. Leek, S. and Christodoulides, G. (2012) ‘A framework of brand value in B2B markets: The contributing role of functional and emotional components', Industrial Marketing Management, 41, pp. 106-114.

Martin, J. E. and Hetrick, S. (2006) Corporate reputations, branding and people management. Oxford: Butterworth-Heinemann.

Miles, M. B., Huberman, A. and Saldana, J. (2014) Qualitative data analysis: A method sourcebook. 3rd edn. Thousand Oaks, CA: Sage Publications.

Miller, L. (2013) FSA answers IFA's top RDR questions, Interlligent-Partnership. Available at: https://intelligent-partnership.com/fsa-answers-ifas-top-rdr-questions/ (Accessed: 15 March 2020).

Mogaji, E., Czarnecka, B. and Danbury, A. (2017) ‘Emotional appeals in UK business-to-business financial services advertisements’. doi: 10.1108/IJBM-09-20160127.

Moin, S. M. A., Devlin, J. and McKechnie, S. (2016) 'The magic of branding: The 
role of "pledge”, "turn” and "prestige” in fostering consumer trust in financial services’, Journal of Financial Services Marketing, 21(2), pp. 113-126. doi: 10.1057/fsm.2016.8.

Paswan, A. K. et al. (2004) 'Search quality in the financial services industry: A contingency perspective’, Journal of Services Marketing, 18(5), pp. 324-338.

Du Preez, R. (2017) 'Internal branding experiences in the financial services sector in South Africa', Journal of Financial Services Marketing, 22(1), pp. 24-32. doi: 10.1057/s41264-017-0018-5.

Raggio, R. D. and Leone, R. P. (2007) 'The theoretical separation of brand equity and brand value: managerial implications for strategic planning', Journal of Brand Management, 14(5), pp. 380-395.

Rambocas, M., Kirpalani, V. M. and Simms, E. (2014) 'Building brand equity in retail banks: The case of Trinidad and Tobago', International Journal of Bank Marketing, 32(4), pp. 300-320. doi: 10.1108/IJBM-11-2013-0136.

Saunders, M., Lewis, P. and Thornhill, A. (2009) Research methods for business students. 5th edn. Harlow: Pearson Education Limited.

Sobh, R. and Perry, C. (2006) 'Research design and data analysis in realism research', European Journal of Marketing, 40(11/12), pp. 1194-1209.

Stockman, S., Hoye, G. Van and Veiga, M. (2020) 'Negative word-of-mouth and applicant attraction: The role of employer brand equity', Journal of Vocational Behavior. Elsevier, 118(December 2019), p. 103368. doi: 10.1016/j.jvb.2019.103368. Tam, J. L. M. (2006) 'Analysis papers: Managing customer expectations in financial services: Opportunities and challenges’, Journal of Financial Services Marketing, 11(4), pp. 281-289.

Theurer, C. P. et al. (2018) 'Employer Branding : A Brand Equity-based Literature 
Review and Research Agenda’, 20, pp. 155-179. doi: 10.1111/ijmr.12121.

Zhang, J. et al. (2016) 'How brand orientation impacts B2B service brand equity? An empirical study among Chinese firms’, Journal of Business \& Industrial Marketing, 31(1), pp. 83-98. doi: 10.1108/JBIM-02-2014-0041. 